\title{
AVALIAÇÃO POR RAPD DE PLANTAS DE ABACAXIZEIRO CULTIVAR SMOOTH CAYENNE DERIVADAS DO SECCIONAMENTO DO TALO E CULTURA DE TECIDOS'.
}

\author{
MARIA VITÓRIA CECCHETTI GOTTARDI², ELIANA GERTRUDES MACEDO LEMOS³, \\ CARLOS RUGGIERO ${ }^{4}$
}

\begin{abstract}
RESUMO - Foram coletadas, em área comercial da fazenda Córrego dos Bois, município de Canápolis - MG, plantas de abacaxizeiro cultivar Smooth Cayenne, para serem avaliadas quanto à propagação pelo método do seccionamento do talo e cultura de tecidos, bem como análise por RAPD das mudas decorrentes destes dois processos de propagação. A propagação pelo seccionamento do talo foi eficiente na produção de mudas, tanto em quantidade como em qualidade, em um curto espaço de tempo, além de apresentar a mesma característica genotípica (análise por RAPD) das plantas-matrizes de origem. Já no processo de produção de mudas por cultura de tecidos, não foi obtida uma quantidade suficiente de mudas que comprovasse a utilização de uma metodologia mais sofisticada. Além da perda por contaminação em laboratório de $70 \%$ do material em estudo, foi necessária a utilização de um longo período, aproximadamente 18 meses, para a obtenção das mudas. Na análise por RAPD das plantas decorrentes deste processo de propagação, foram observados padrões de bandas diferentes em algumas amostras, as quais podem estar relacionadas com uma possível variação somaclonal.
\end{abstract}

Termos para indexação: Ananas comosus, PCR, polimorfismo, variabilidade genética.

\section{EVALUATION OF PINEAPPLE PLANTS CULTIVAR SMOOTH CAYENNE FROM PEDUNCLE DIVISION AND TISSUE CULTURE BY RAPD}

\begin{abstract}
Plants of pineapple Smooth Cayenne cultivar were collected from a commercial area, Córrego dos Bois farm, in Canápolis, state of Minas Gerais, to evaluate two different processes of propagation, peduncle division and tissue culture. These same plants were characterized by RAPD analysis. According to the two propagation method, the peduncle division was efficient in seedlings propagation, in quantity as well as in quality, at a short period of time, resulting the same phenotype and genetic characteristics (RAPD analysis) from the matrix descent plants. In the tissue culture method, the quantity of seedlings obtained were not good enough that could prove the use of a sophisticated methodology. Besides loosing $70 \%$ of the material, it was necessary to expend a long period of time, at least 18 months to obtain the new seedlings. By RAPD analysis of plants obtained by tissue culture were observed different patterns in some samples, those could be related to somaclonal variation.
\end{abstract}

Index terms: Ananas comosus, PCR, polymorphism, genetic variability.

\section{INTRODUÇÃO}

Muitos são os problemas que têm contribuído para impedir a expansão da abacaxicultura no Brasil, dentre os quais podemos destacar: a falta de mudas de boa qualidade e em quantidade suficiente para formação de novas lavouras, ocorrência de pragas e doenças, ausência de viveiristas, inexistência de mudas fiscalizadas, entre outros (Ruggiero et al., 1994; Gorgatti et al., 1996; Cunha et al., 1999).

Na prática, o abacaxizeiro é propagado vegetativamente, por meio de mudas, cuja qualidade é fator decisivo para obtenção de lavouras uniformes, de bom estado fitossanitário e altamente produtivas (Usberti Filho et al., 1995).

Este tipo de propagação torna-se um fator limitante para o melhor desenvolvimento da abacaxicultura no Brasil, já que é ausente a figura do viveirista, levando os produtores a adquirirem mudas em plantios comerciais ou até mesmo nos CEASAs, o que compromete a qualidade do material (Ruggiero et al., 1994).
Observa-se, por outro lado, que pesquisas realizadas têm desenvolvido métodos de propagação mais adequados que proporcionam a obtenção de mudas sadias, de boa qualidade e em quantidade suficiente para formação de novas lavouras.

A propagação pelo seccionamento do talo é um método simples, que permite a formação de mudas através do desenvolvimento de gemas axilares de pedaços (secções) do talo da planta-mãe. Este processo pode ser usado, não só para obtenção de mudas livres de pragas e doenças, mas também para produção de mudas de boa qualidade em um curto espaço de tempo (Cunha \& Reinhardt, 1994).

Outra técnica consiste na produção de mudas por cultura de tecidos, a partir de meristemas e de gemas apicais ou laterais. A micropropagação "in vitro" é uma técnica mais elaborada, pois envolve laboratórios especializados para realização deste processo. Entretanto, este método pode ser usado não só para a produção de mudas sadias e de boa qualidade, mas também quando há escassez de material para o 
plantio (Cunha et al., 1999).

Embora muitos estudos tenham sido desenvolvidos com abacaxi, esta é uma planta pouco conhecida sob o ponto de vista genético. Com os avanços biotecnológicos, tem sido crescente a utilização de técnicas de marcadores de DNA no estudo da diversidade genética em plantas. Técnicas como determinação de padrões isoenzimáticos ou amplificação casualizada de DNA polimórfico (RAPD) têm sido empregadas na busca de verificar variações somaclonais, mutações e polimorfismo, entre outras (Ferreira \& Grattapaglia, 1996).

Segundo Golembiewsk et al. (1997), o uso de marcadores RAPD permite a pesquisa de indivíduos dentro de uma população heterogênea e baseia-se na identificação de proporções de polimorfismo e de marcadores compartilhados, permitindo a identificação do parentesco entre cultivares e inferências da diversidade existente entre e dentro de cultivares.

Ruas et al. (1995), em estudos realizados com abacaxi, utilizaram 17 "primers" em reações de RAPD, produzindo 75 marcadores, que permitiram a discriminação de 4 cultivares de abacaxi. Os resultados obtidos, destas análises de RAPD, foram similares àqueles obtidos nas avaliações morfológicas $\mathrm{e}$ agronômicas, levando os autores a concluírem que análises de RAPD podem ser usadas de maneira eficiente para caracterização de recursos genéticos no gênero Ananas.

O presente estudo teve como objetivo avaliar a viabilidade do processo de propagação pelo seccionamemto do talo e cultura de tecidos ("in vitro"); avaliar geneticamente, empregando-se marcadores moleculares, as plantas decorrentes desses dois processos de propagação, comparando-as com as matrizes de origem.

\section{MATERIAL E MÉTODOS}

Foram coletadas 20 plantas adultas de abacaxizeiro cultivar Smooth Cayenne, em área comercial existente na Fazenda Córrego dos Bois, município de Canápolis - MG. As coroas destas plantas foram utilizadas para propagação "in vitro", e os talos foram submetidos à propagação pelo método do seccionamento do talo.

A propagação pelo método do seccionamento do talo foi desenvolvida segundo metodologia descrita por Ventura (1994) e Cunha \& Reinhardt (1994), e a propagação por cultura de tecidos foi realizada em laboratórios qualificados, a saber: $\mathrm{Cia}$ de Promoção Agrícola "CAMPO" - Paracatu-MG, e Instituto Agronômico de Campinas (IAC), devido ao fato de esses laboratórios já estarem envolvidos na produção de mudas de abacaxi. Para tanto, foram enviadas 10 coroas à CAMPO e 10 coroas ao Instituto Agronômico de Campinas (IAC).

Após a propagação e o estabelecimento das plantas, estas foram transferidas para o campo, em área pertencente ao Departamento de Produção Vegetal da FCAV - UNESP. Após o plantio, estas mudas tiveram amostras de folhas retiradas para análise por RAPD.

\section{Análise por marcadores RAPD}

Para a extração do DNA, foi utilizada a técnica proposta por Lin \& Kuo (1998), utilizando Plant DNAzol (Gibco BRL) - reagente para extração de DNA genômico. Foram extraídos os DNAs das folhas de 75 amostras propagadas por cultura de tecidos; 120 amostras propagadas por seccionamento do talo; bem como das 20 plantas-matrizes coletadas na fazenda Córrego dos Bois para comparação com suas descendentes, decorrentes dos dois processos de propagação.

A quantificação do DNA foi realizada em espectrofotômetro, medindo-se a absorbância nos comprimento de onda de 260 e $280 \mathrm{~nm}$. A reação de amplificação constituiu-se de 30 ng de DNA genômico, tampão de PCR (20mM Tris-HCl pH 8,0 e $50 \mathrm{mM} \mathrm{KCL}$ ) (GIBCO-BRL), $\mathrm{MgCl}_{2} 1,5 \mathrm{mM}$ (GIBCO-BRL), $200 \mathrm{mM}$ de dNTPs, $1,0 \mathrm{u}$ de Taq DNA polimerase (GIBCO-BRL), $0,22 \mathrm{mM}$ de "primer", água milli Q q.s.p. $20 \mathrm{~mL}$. Os tubos foram colocados em um aparelho termociclador (PTC-100 Programable Thermal Controler- MJ Reserch, Inc.) e submetidos a um ciclo de: $92^{\circ} \mathrm{C}$ por 3 minutos, 47 ciclos a $92^{\circ} \mathrm{C}$ por 1 minuto, $36^{\circ} \mathrm{C}$ por 1 minuto e 45 segundos e $72^{\circ} \mathrm{C}$ por 2 minutos e, finalmente, $72^{\circ} \mathrm{C}$ durante 7 minutos (Ruas et al., 1995). Os "primers" utilizados foram: 226 (CCACTCACCG), 228 (AGGCCGCTTA), 239 (CTGAAGCGGA), 204(TTCGGGCCGT), 259(TGCAGTCGAA), 264 (TCCACCGCGC), 231 (AGGGAGTTCC), 240 (ATGTTCCAGG), 248(GAGTCTACCG) e 256 (TGCAGTCGAA), produzidos pela University of British Columbia (RAPD Oligo Project) - Biotechnology Laboratory. As amostras amplificadas foram submetidas 'a eletroforese $(100 \mathrm{~V}-1 \mathrm{~h} 30 \mathrm{~min}) \mathrm{em}$ gel de agarose a 1,5\%, dissolvido em tampão TEB [ $89 \mathrm{mM}$ - ácido bórico, $89 \mathrm{mM}$ - Tris, 2,5mM - EDTA, contendo brometo de etídio $(0,05 \mu \mathrm{g} /$ $\mathrm{ml})$ e $\mathrm{H}_{2} \mathrm{O}$ milli- Q]. Como padrão de peso molecular, foi utilizado "ladder" de $1 \mathrm{~kb}$ (GIBCO-BRL). A visualização dos resultados foi realizada em equipamento de fotodocumentação (Gel Doc- 1000 - BioRad).

\section{RESULTADOS E DISCUSSÃO}

- Propagação pelo seccionamento do talo

Foram obtidas em um período de 8 meses, decorrentes de 20 talos com secções de $10 \mathrm{~cm}$ cortadas ao meio, aproximadamente 6,5 mudas por talo de plantas-matrizes, resultando um total de 130 mudas. Foi observado que algumas secções das matrizes de número $01 ; 09 ; 14$ e 15 produziram mais de uma muda, fato este devido à presença de mais de uma gema vegetativa na secção (Tabela 1).

O método do seccionamento do talo, quando comparado com a propagação pelo método convencional, onde se obtém na cultivar Smooth Cayenne de zero a 3 filhotes e um a dois rebentões por planta, em um período de aproximadamente 18 meses (Cunha et al., 1999), torna-se viável, ou seja, produz um maior número de mudas em um menor espaço de tempo, além de permitir um exame visual das mudas para verificar incidência de pragas e doenças, principalmente a ocorrência da fusariose.

- Propagação por cultura de tecidos

Das 10 coroas de plantas-matrizes enviadas para a firma de Biotecnologia CAMPO, apenas 3 foram propagadas com sucesso, sendo obtidas 4 mudas da matriz de número $3 ; 1.700$ mudas da matriz de número 7 ; e 1.500 mudas da matriz de número 9; o restante foi perdido por contaminação. Das 3.204 mudas obtidas, foram utilizadas para o plantio no campo 4 mudas da matriz de número 3; 500 mudas da matriz de número 7; e 500 
TABELA 1- Produção de mudas pelo processo de seccionamento do talo

\begin{tabular}{|c|c|c|c|c|c|}
\hline M A T R IZ & $\begin{array}{c}\text { T O T A L D E } \\
\text { S E C Ç Õ E S } \\
\text { P L A N T A D A S } \\
(02-04-98)\end{array}$ & $\begin{array}{c}\text { T O T A L D E } \\
\text { P LA N T A S } \\
\text { S A D IA S } \\
\text { O B T ID A S ( } 19- \\
02-99)\end{array}$ & $\begin{array}{c}\text { PLA N TA S } \\
\text { ELIM IN A D A S }\end{array}$ & $\begin{array}{l}\text { T O T A L D E M U D A S } \\
\text { S A D IA S } \\
\text { PLA N T A D A S N O } \\
\text { C A M P O } \\
(19-02-99)\end{array}$ & $\begin{array}{l}\text { TO T A L D E } \\
\text { P LA N T A S } \\
\text { EX IS T EN T ES } \\
\text { N O C A M P O } \\
(19-09-00)\end{array}$ \\
\hline 01 & 10 & 11 & --- & 11 & 11 \\
\hline 02 & 08 & 4 & 3 & 4 & 4 \\
\hline 03 & 12 & 12 & $-\ldots$ & 12 & 8 \\
\hline 04 & 08 & 3 & 2 & 3 & 3 \\
\hline 05 & 10 & 7 & $-\ldots$ & 7 & 7 \\
\hline 06 & 12 & 5 & $-\ldots$ & 5 & 5 \\
\hline 07 & 08 & 8 & --- & 8 & 8 \\
\hline 08 & 10 & 6 & 1 & 6 & 6 \\
\hline 09 & 10 & 14 & $-\cdots$ & 14 & 12 \\
\hline 10 & 08 & 4 & --- & 4 & 4 \\
\hline 11 & 06 & 3 & 1 & 3 & 3 \\
\hline 12 & 08 & 3 & 1 & 3 & 3 \\
\hline 13 & 06 & 3 & 1 & 3 & 3 \\
\hline 14 & 08 & 10 & 2 & 10 & 7 \\
\hline 15 & 08 & 10 & 1 & 10 & 9 \\
\hline 16 & 08 & 7 & 1 & 7 & 7 \\
\hline 17 & 08 & 7 & --- & 7 & 7 \\
\hline 18 & 08 & 4 & --- & 4 & 4 \\
\hline 19 & 10 & 3 & 1 & 3 & 3 \\
\hline 20 & 08 & 6 & 1 & 6 & 6 \\
\hline 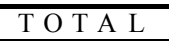 & 174 & 130 & 15 & 130 & 120 \\
\hline
\end{tabular}
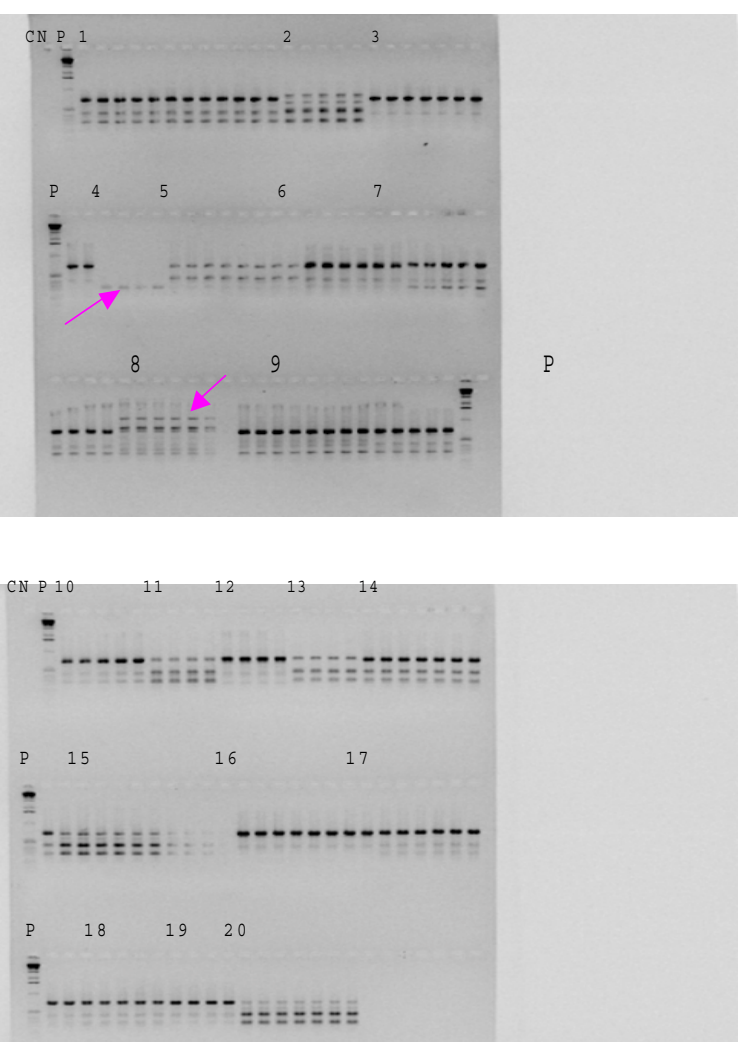

FIGURA 1 - Padrões de bandeamento de fragmentos de DNA amplificados por RAPD das amostras de plantasmatrizes/descendentes, derivadas do seccionamento do talo, utilizando-se do "primer" BC 259: $(\mathrm{CN})$ controle negativo; $(\mathrm{P})$ padrão de peso molecular $1 \mathrm{~Kb}$; (números de 1 a 20) amostras das plantas-matrizes; (canaletas ao lado sem número) indicam, respectivamente, as amostras descendentes do processo de seccionamento do talo; (seta) bandas polimórficas.
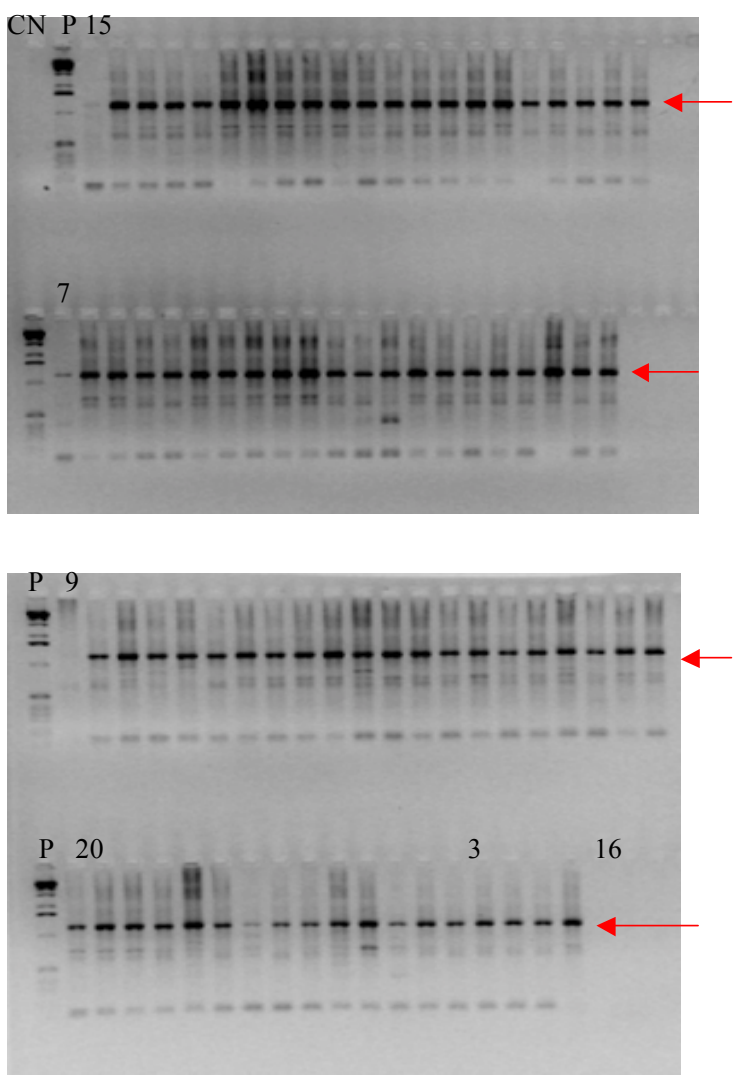

FIGURA 2 - Padrões de bandeamento de fragmentos de DNA amplificados por RAPD das amostras de plantasmatrizes/descendentes, derivadas da propagação "in vitro", utilizando-se o "primer" BC 226: (CN) controle negativo; $(\mathrm{P})$ padrão de peso molecular $1 \mathrm{~Kb}$; (números 15; 7; 9; 20; 3 e 16) amostras das plantas-matrizes; (canaletas ao lado sem número) indicam, respectivamente, as amostras descendentes do processo de propagação "in vitro"; (setas) bandas monomórficas. 

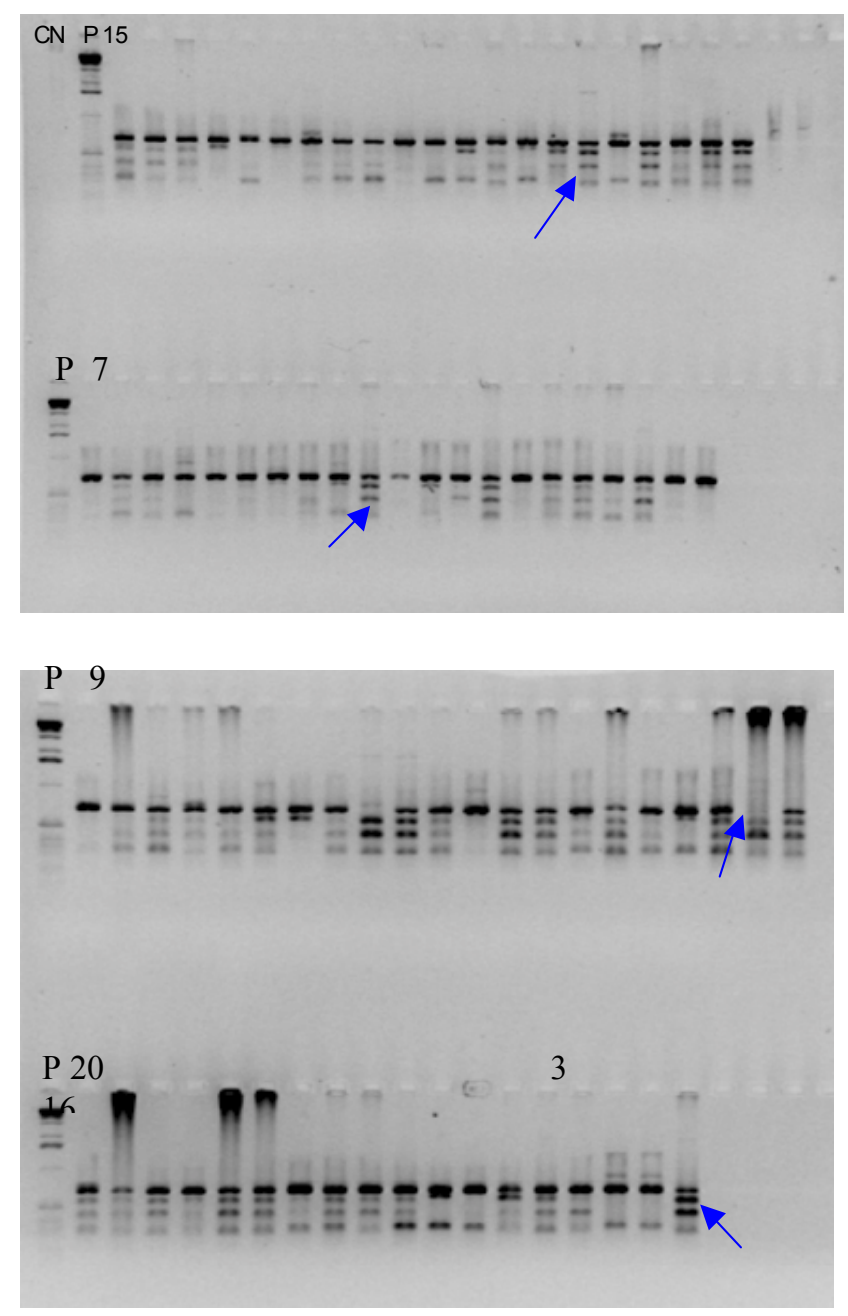

FIGURA 3 - Padrões de bandeamento de fragmentos de DNA amplificados por RAPD das amostras de plantasmatrizes/descendentes, derivadas da propagação "in vitro", utilizando-se o "primer” BC 259: (CN) controle negativo; (P) padrão de peso molecular $1 \mathrm{~Kb}$; (números 15; 7; 9; 20; 3 e 16) amostras das plantas-matrizes; (canaletas ao lado sem número) indicam, respectivamente, as amostras descendentes do processo de propagação "in vitro"; (setas) bandas diferenciadas.

mudas da matriz de número 9.

Da mesma forma, ocorreu no Instituto Agronômico de Campinas (IAC), onde apenas 3 coroas de plantas matrizes foram propagadas; entretanto, foi obtido um menor número de mudas por coroa, sendo 2 mudas da matriz de número 16; 16 mudas da matriz de número 20; e 80 mudas da matriz de número 15 . O insucesso ocorreu devido à perda por contaminação, baixa taxa de germinação das gemas inoculadas e, em alguns casos, esta germinação não ocorreu. Todas as 98 mudas obtidas foram utilizadas para o plantio no campo.

Embora a propagação por cultura de tecidos tenha sido desenvolvida em laboratórios qualificados (Firma de Biotecnologia "Campo" e Instituto Agronômico de Campinas IAC), houve uma perda significativa do material em estudo, restando poucas matrizes para serem propagadas, ou seja, 20 coroas de plantas-matrizes foram enviadas para os laboratórios, mas apenas 6 coroas foram utilizadas na propagação. Dentre as 6 matrizes propagadas, além do longo período utilizado para esta multiplicação, aproximadamente 18 meses, não foi obtida uma quantidade de mudas esperada.

Ventura (1994) relata que a maioria dos trabalhos com micropropagação de abacaxizeiro se refere ao estabelecimento e composição dos meios de cultura, sem considerar o número de plantas regeneradas em função do tempo e o efeito dos genótipos utilizados, indicando que as técnicas de cultura "in vitro" do abacaxizeiro ainda não estão totalmente dominadas para a maioria das cultivares, desconhecendo-se, também, a possível variabilidade induzida no processo.

Entretanto, podemos observar, através das dificuldades surgidas, que esta técnica de propagação ("in vitro") precisa ser melhor estudada, principalmente em relação à quantidade e ao tempo necessário para produção de mudas, estabelecimento das culturas "in vitro", porcentagem de pegamento no campo e avaliação fenotípica das plantas.

\section{- Marcadores RAPD}

1) Seccionamento do talo

Dentre os 100 "primers" testados para a amplificação do DNA genômico das plantas-matrizes, foram selecionados 10, os quais forneceram maior número de bandas, para a utilização nas análises de RAPD das plantas propagadas pelo seccionamento do talo.

Para a análise de RAPD, foram utilizados os DNAs das 120 plantas existentes no campo, decorrentes do processo de seccionamento do talo, bem como os DNAs das 20 plantasmatrizes, para posterior comparação.

Através da técnica de RAPD, pôde-se observar que as plantas decorrentes do seccionamento do talo mostraram um perfil diferente quando da utilização de um mesmo "primer". De um modo geral, os 10 "primers" selecionados geraram um número apreciável de bandas, principalmente em relação à intensidade.

$\mathrm{Na}$ análise entre plantas-matrizes/descendentes, obtiveram-se padrões de bandas diferentes, indicando a existência de variabilidade genética; entretanto, "dentro" de cada matriz/ descendente, não houve variabilidade genética, ou seja, as plantas decorrentes do seccionamento do talo mantiveram as mesmas características das matrizes, indicando, desta forma, que geneticamente são iguais, ou seja, são clones de suas matrizes. Este fato que pode ser observado na Figura 1, utilizando como exemplo o "primer" BC 259. Também foram encontradas bandas monomórficas, que estão relacionadas com as características da variedade em estudo.

Através destes resultados, pode-se observar que as plantas propagadas pelo seccionamento do talo conservam as mesmas caraterísticas genéticas das plantas-matrizes, proporcionando desta forma a obtenção de clones que garantirão um material geneticamente igual à planta-mãe e de boa qualidade.

\section{2) Cultura de tecidos}

Para análise de RAPD das plantas propagadas por cultura de tecidos, foram utilizados os 10 "primers" selecionados na análise das plantas decorrentes do seccionamento do talo.

Foram utilizados para esta análise, os DNAs de 75 plantas decorrentes da propagação por cultura de tecidos, sendo 3 plantas decorrentes da matriz de número 3; 20 plantas 
decorrentes da matriz de número 7; 20 plantas da matriz de número $9 ; 2$ plantas da matriz de número $16 ; 10$ plantas da matriz de número 20 ; e 20 plantas da matriz de número 15 , bem como as matrizes correspondentes coletadas na fazenda Córrego dos Bois - MG, para posterior comparação.

Através das análises de RAPD, pôde-se observar que as plantas propagadas por cultura de tecidos apresentaram, em todos os "primers" utilizados, bandas monomórficas, fato evidente na utilização de plantas da mesma cultivar (Figura 2). Entretanto, foram observados, em algumas amostras dentro das plantas descendentes, padrões de bandas diferentes para alguns dos "primers" utilizados (Figura 3). Segundo Benega et al. (1996), a variação somaclonal proveniente da instabilidade genética das divisões celulares não homogêneas do tecido dos calos tem levado a uma regeneração de indivíduos diferenciados.

A variação somaclonal em plantas cultivadas "in vitro" está freqüentemente associada a alterações cromossômicas, podendo ocorrer deleção ou duplicação das seqüências de determinados genes, originando plantas com características indesejáveis (Ventura et al., 1994).

Pode-se considerar que a produção de mudas de abacaxi por cultura de tecidos é um processo viável; entretanto, a metodologia precisa ser melhor adequada, uma vez que foi verificada uma perda de $70 \%$ do material em decorrência da ausência de desenvolvimento das gemas inoculadas, assim como o comprometimento com contaminantes.

Desta forma, fica evidente a maior eficácia da propagação pelo seccionamento do talo, onde as mudas se desenvolveram a contento, não ocorrendo perda por contaminação, como também não foi observada variação somaclonal.

\section{CONCLUSÕES}

1) A propagação pelo método do seccionamento do talo foi eficiente na produção de mudas de abacaxizeiro, tanto em quantidade quanto em qualidade, além de se manterem geneticamente idênticas às plantas-matrizes.

2) A propagação "in vitro" para a cultivar Smooth Cayenne não foi eficiente, sendo necessárias novas pesquisas para se adequar os protocolos, desde o recebimento do material, até as técnicas inerentes ao processo a nível de laboratório, para que possamos utilizar com segurança esta técnica na formação de novas lavouras.

\section{AGRADECIMENTOS}

Ao IAC e à CAMPO, pelo auxílio na produção de mudas por cultura de tecidos, ao Eng. Agr ${ }^{\circ}$ José Roberto da Silva (EMATER) - Monte Alegre de Minas, pelo auxílio prestado na coleta das plantas-matrizes no campo, e à FAPESP, pelo auxílio financeiro.

\section{REFERÊNCIAS BIBLIOGRÁFICAS}

BENEGA, R. et al. Germinación in vitro y formación de callos en semillas de piña (Ananas comosus (L.) Merr.). Pineapple News, Honolulu, v.2, n.1, p.9-11, 1996.

CUNHA, G.A P.; REINHARDT, H.R.C. A propagação do abacaxizeiro. Brasília: EMBRAPA 1994. p.7-67. (Coleção Plantar, 11).

CUNHA, G.A P.; CABRAL, J.R.S.; SOUZA, L.F.S. O abacaxiziero: cultivo, agroindústria e economia. Brasília: EMBRAPA, 1999. 480p.

FERREIRA, M.E.; GRATTAPAGLIA, D. Introdução ao uso de marcadores moleculares em análise genética. Brasília: Embrapa, 1996.220p.

GOLEMBIEWSK, R.C.; DANNEBERGER, T.K.; SWEENEY,P.M. Potential of RAPD markers for use in the identification of creeping bentgrass cultivar. Crop Science, Madison, v.37, p.212-214, 1997.

GORGATTI, A N. et al. Abacaxi para exportação: procedimentos de colheita e pós-colheita. Brasília: Frupex. 1996. 41p.

LIN, J.J.; KUO., J. A new reagent for simple isolation of plant genomic DNA. Plant Biotecnology, v.20, n.2, p.46-48, 1998.

RUGGIERO, C.; NOGUEIRA FILHO, G.C; GOTTARDI, M.V.C. Considerações gerais sobre a cultura do abacaxizeiro no Brasil. In : RUGGIERO, C: Controle integrado da fusariose do abacaxizeiro. Jaboticabal: FUNEP, 1994.p.1-14.

RUAS, P.M. et al. Genetic relatonship among four varieties by pineaple, Ananas comosus, reveable by random amplified polymorphic DNA (RAPD) analysis. Revista Brasileira de Genética, Campinas, v.18, n.3, p.413-416, 1995.

USBERTI FILHO, J.A. et al. Inheirtance of leaf spininess and segregation of leaf color in pineaple (Ananas comosus L.Merrill) Revista Brasileira de Genética, Campinas, v.18, n. 4, p. 547-552, 1995.

VENTURA, J.A. Propagação do abacaxizeiro por divisão do talo. In RUGGiero, C. Controle integrado da fusariose do abacaxizeiro. Jaboticabal: FUNEP, 1994. p.35-41.

VENTURA, J.A.; ZAMBOLIM, L.; CHAVES, G.M. Propagação por biotecnologia: micropropagação "in vitro" do abacaxizeiro. In: RUGGIERO, C. Controle integrado da fusariose do abacaxizeiro. Jaboticabal: FUNEP, 1994. p.43-51. 